\title{
Research on Legal Regulation of Third Party Payment in Internet Finance
}

\author{
Mu Chenlu \\ Tianjin University, Tianjin, 300072, China
}

Keywords: Legal Regulation, Third Party Payment, Internet Finance

\begin{abstract}
The third-party payment refers to the acquisition of the license by the business as a separate entity from both parties to the transaction in an open network environment through data exchange and verification of information. Users and commercial banks can achieve network payment connection function, the final buyers, sellers and commercial banks in the payment platform complete a transaction settlement. Third-party payment provides a convenient fund circulation channel for online transactions and promotes the rapid development of Internet finance. However, due to the imperfect legal system in China, there are still some risks and problems that need to be solved in the third-party payment industry. Based on the analysis of the status quo and legislative defects of third-party payment in Internet finance, this paper puts forward suggestions for constructing legal supervision mechanism of third-party payment in order to standardize and promote the development of third-party payment industry in Internet finance.
\end{abstract}

\section{Introduction}

In 2013, the development of Internet finance in our country started after the advent of the balance treasure, and "Internet finance" was written into the government work report. Different from the previous "promotion" development, Premier Li Keqiang explicitly puts forward the key work in 2016 to standardize the development of Internet finance and achieve full coverage of financial risk supervision [1]. Third-party payment has provided access to funds and hosting services for Internet finance, and it has a very broad market prospects. However, it faces many risks and there is an urgent need to strengthen supervision [2]. In Figure 1, the Internet finance third party payment development status and risk is given in details.

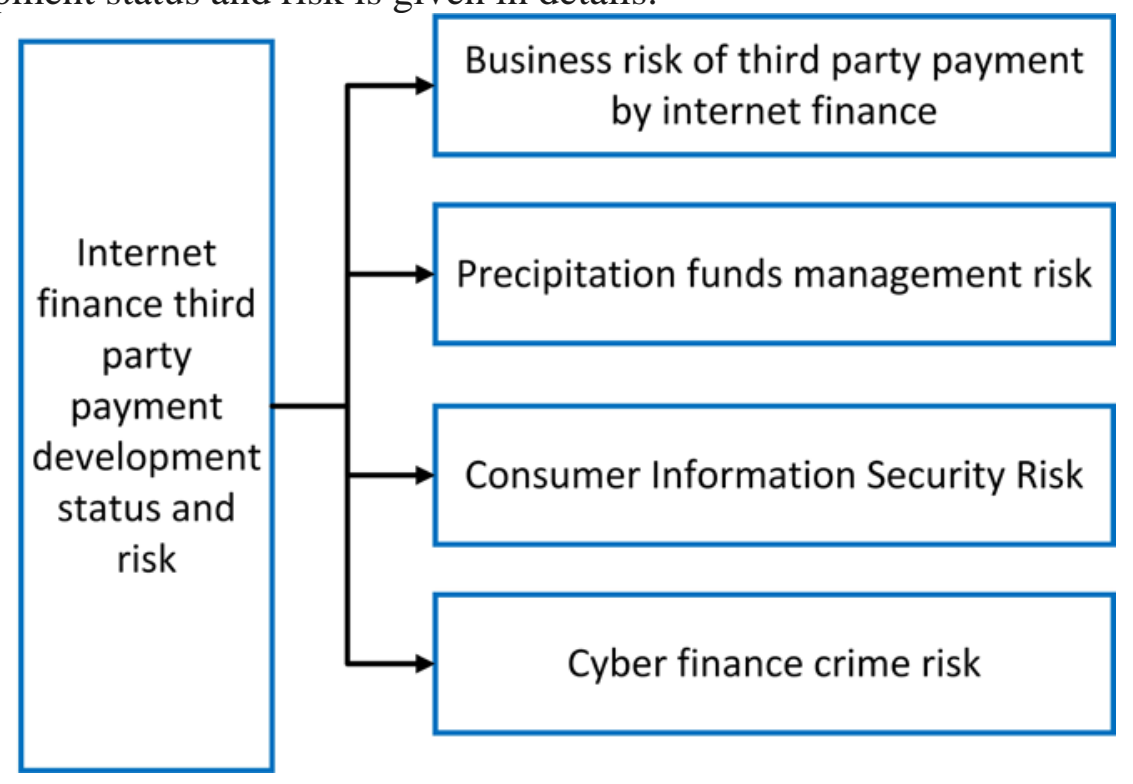

Figure 1: Internet finance third party payment development status and risk

\section{The Status Quo and Risk of Third Party Payment in Internet Finance in China}

The so-called third-party payment refers to the acquisition of the license by the business as a separate entity from both parties to the transaction. All commercial banks establish an agreement 
relationship in an open network environment through data exchange and verification of information [3]. Users and commercial banks can achieve network payment connection function, the final buyers, sellers and commercial banks in the payment platform to complete a transaction settlement. According to the "Brief Version of Annual Monitoring Report on Third-Party Payment Industry in China", the payment scale of Internet transactions in China reached 5.37 trillion in 2013, of which Alipay accounted for $48.7 \%$. In order to standardize the payment behavior of non-financial institutions, the People's Bank of China promulgated the measures for the administration of payment services of non-financial institutions in 2010, and clearly defined the business license system, which marked that the third-party payment platform of our country was officially incorporated into the national regulatory field [4]. The third-party payment establishes the connection between the user and the bank and brings great convenience to the main body of the online transaction. And the guarantee function also improves the transaction security. However, the risks it brings can not be neglected, while the third-party payment of internet finance is developing rapidly [5].

\subsection{Business risk of third party payment by internet finance}

Third-party payment agencies often promote their advantages and benefits with recommending the new payment products without any indication of the risks. For example, when Alipay launches its business, it promises that its return would be much higher than that of bank deposits over the same period, however it does not remind investors about the investment risk of the fund. Although the procedure is simple and quick, however its convenience inherently contains legal risks. Third-party payment agencies fail to inform the obligation to prompt the lack of business risks and infringe the consumer's right to know [6].

\subsection{Precipitation funds management risk}

In the law, Announcement "Depository Institutions for Customers' Deposits and Reserves" is called customer reserve payment, which specifically means the payment actually received by the payment institution for the payment business commissioned by the customer. In addition to the buyer's prepayments, the customer's prepayments also include funds pre-deposited by the customer in the payment platform, such as the seller's deposit. Although the settlement fund is not owned by the third-party payment platform, it is actually controlled and can be used without the customer's knowledge.

\subsection{Consumer Information Security Risk}

Consumers and third-party payment platform establishes service relations through the format of the contract, and both sides of the information asymmetry and consumers are in a weak side. In online payment and settlement process, consumers need to register personal information by the payment platform for review [7]. If the third-party payment platform is not well-kept and the information is illegally used, it will result in the disclosure of personal information.

\subsection{Online financial crime risk}

As the third party payment of Internet finance makes it easy to hide the true identity through the internet trading platform, the bank cannot effectively regulate the use and flow of funds which providing criminals with opportunities [8]. They make use of online virtual transactions to illegally transfer funds to engage in criminal activities such as cyber gambling and money laundering.

\section{Main Problems in Legal System of Third Party Payment in Internet Finance in China}

The main legal basis for the regulation of third-party payment in China is the measures for the Administration of Payment Services of Non-Financial Institutions. The promulgation of this measure marks the central bank's recognition of the market position of third-party payment agencies. In order to enhance operability, the PBOC also promulgates the detailed rules for the implementation of the measures for the administration of payment services, elaborates and 
explaines the principle provisions [9]. On June 7, 2013, the measures on deposit preparedness for payment institutional customers clarify the management of customer preparation and payment, which is in favor of the protection of the legitimate rights and interests. Although a series of legal documents have been promulgated, some problems still exist, which are mainly in the following aspects (as shown in Figure 2).

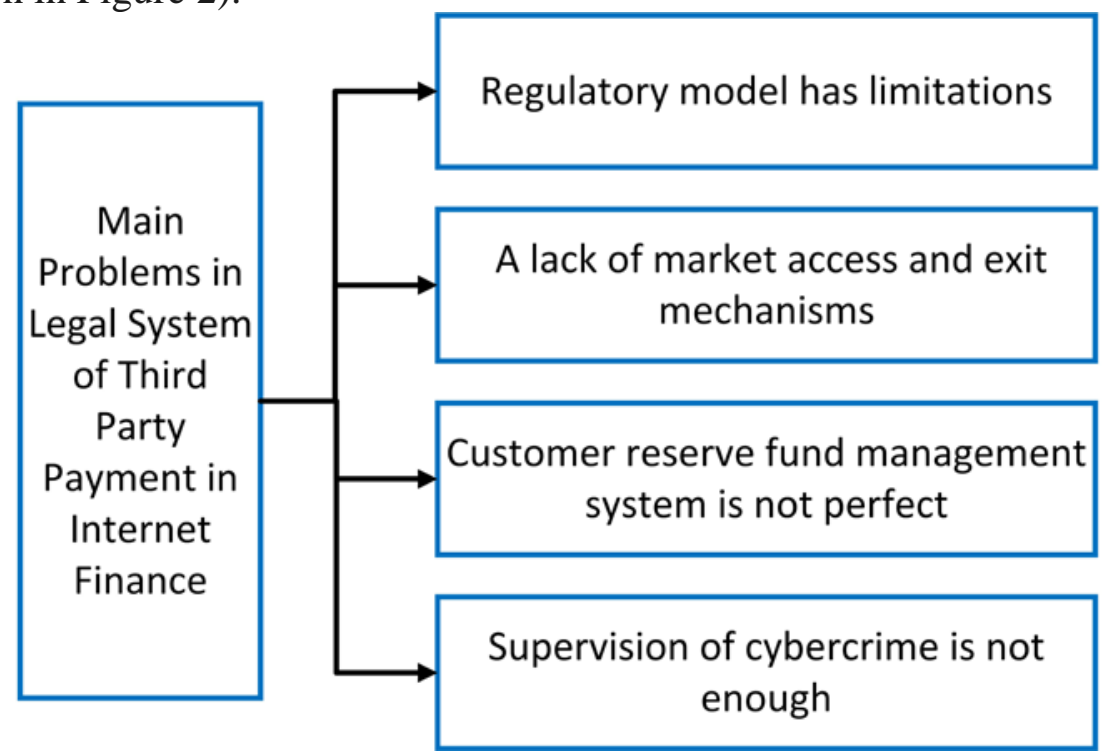

Figure 2: Main problems in legal system of third party payment in Internet finance

\subsection{Regulatory model has its limitations}

The "Non-financial Institutions Payment Service Management Measures" clarifies that the third party payment agency's regulatory body is the People's Bank of China. Third-party payment agencies are mainly engaged in payment and settlement businesses, which are compatible with the supervision functions of the central bank [10]. However, due to their combination with Internet technologies, it is clearly not enough to rely solely on the central bank. It is necessary to unite different government departments to integrate resources and complement each other's advantages. However, the two authorities should make reasonable judgments on regulatory authority, and no effective linkage mechanism has been formed yet. In addition, their respective advantages have not been fully developed to achieve the regulatory effectiveness.

Information technology and technical requirements for third-party payment in Internet finance require that internal control mechanisms be strengthened to prevent staff from embezzling customer information and other criminal activities. However, it is not enough to set up the internal control mechanism only by the rules and regulations. It also needs the law to standardize and clarify the main responsibility, sets the corresponding obligations to the third-party payment agencies, and urges them to establish a more complete self-evaluation system. Once a third-party payment institution discovers a problem or changes major issues, it shall report and publicize to the regulatory authorities and clients.

\subsection{Lack of market access and exit mechanisms}

The market access system is a prerequisite for the state to supervise the market economy, and it is also an important prerequisite for ensuring the healthy operation of the third-party payment industry. The measures for the administration of payment services regulate the conditions for payment of business licenses [4]. However, the excessive statutory registered capital is not conducive to the innovation and development of the industry and the protection of the rights and interests. The amount, which is paid for the payment of business across the country, is RMB 100 million. This division of standards seems plausible, but it ignores the cross-regional characteristics of Internet business, payment and settlement activities, which often occur in different regions.

The measures for the administration of payment services provided by non-financial institutions do not make any explicit stipulations on the mechanism for withdrawing from the market. The 
liquidation items that require payment platforms shall only be handled in accordance with the relevant state laws [8]. Although the third-party payment platform is a non-financial institution, it holds a large amount of the user information and huge amounts of funds. Once the non-compliance operation enters the liquidation, revocation or bankruptcy procedures, it may cause heavy losses to the users and even cause the entire third-party payment industry credit damage, which affects the healthy operation of the Internet finance industry [6]. Therefore, the exit mechanism of the third-party payment platform should be strictly controlled through a clear regulatory system, and the system for protecting the user's funds and personal information should be clearly defined.

\subsection{Customer prepaid management system is not perfect}

Securing customer funds is the core issue of third-party payment regulation. With the expansion of third-party payment, more and more deposits are accumulated by the third-party payment platforms. Although the management of non-financial institutions' payment services is clear that the customer reserves are not owned by the paying institutions, any form of diversion is strictly forbidden [5]. Special accounts should be set aside at commercial banks for deposit. Although a risk reserve is withdrawn according to $10 \%$ of the interest on all reserve funds, the "Measures for the Depository and Payment of Institutional Reserve Customers in Payment Institutions" sidesteps the issue of interest attribution. Due to the defects of the legislation, some payment platforms in the practice stipulate in the service agreement that the interest needs not be returned to the customer.

\subsection{Consumer rights protection system is not perfect}

Consumers are apparently at a disadvantage compared with third-party payment agencies and e-commerce companies due to the lack of information, capital and technology. The customer does not have the right to negotiate changes, which result that the rights and interests can not be fully protected. The lack of an intuitive examination by online trading inevitably increases the consumer risk. Coupled with the intermediate links of the logistics company, the difficulty in delineating the liability also increases. The regulations on the payment of services by non-financial institutions and other regulations stipulate the supervision of the reserve fund and the personal information, which are not sufficiently detailed and operable. The provisions are not clear, which resulting in consumer rights protection difficulties [6].

\section{Proposals to Improve the Third Party Payment Supervision System of Internet Finance in China}

\subsection{Improve market access and exit mechanism}

The measures for the administration of payment services of non-financial institutions stipulates that the system for paying business licenses shall be reviewed and issued by the central bank to strengthen the examination of the main qualifications of applicants, which will help avoid market risks. The total turnover of the appropriate minimum registered capital to determine the minimum can meet the cross-regional characteristics of Internet finance. In addition, in order to avoid monopoly industries, we should draw lessons from the market access system of the EU and Singapore. The policies should be properly leveled on SMEs, adopt a conditional exemption system for their market access, reduce the threshold for the establishment of SMEs, and inject new vitality into the development of the industry.

Therefore, we can learn from the advanced legislative experience abroad, first of all clears the third-party payment business confidentiality obligations of customer information. Second, the client funds should take effective measures to allocate, and it shall be compensated with the risk reserve deposited with the commercial bank at the commercial bank.

\subsection{Reform of customer preparation management system}

Customer reserve payments before the third-party payment platform is transferred to the seller, and the ownership should be owned by the buyer due to the nature of the payment process. The interest generated during this phase is actually controlled by the third-party payment platform. In 
addition to the pro-rata risk reserve, there is no rule on how the rest of the interest should be dealt with. In addition, the current law does not regulate the investment channels for customers' reserve payments, which resulting in a large amount of idle funds. In foreign countries, the United States and the European Union allow this part of the funds to be used for low-risk savings and bond investments and stipulate the upper limit and the proportion of total investment. Such a more relaxed regulatory model will not only help ensure basic capital security and get the appropriate return on investment to avoid waste of resources.

\subsection{Improve the protection of consumer rights mechanism}

Legislation should put the information security of financial consumers on the same status as commercial secrets, and clarify the specific obligations of third-party payment platforms to protect the privacy rights of users. If the number of people is too large or has a wide range of impact and cause bad social effects, the market participants should be disqualified and the business license revoked [2]. At the same time, if the third-party payment platform fulfills the duty of diligence, the network environment and the hardware facilities are monitored in compliance with the rules due to unforeseen circumstances such as hacker malicious invasion and customer information disclosure. In addition, it should be made corresponding exemption clauses in order to safeguard the legitimate rights and interests of market participants.

Due to the immediacy and the large quantity of third-party payment of internet finance, the transaction amount of one transaction may be small, and the cost of taking ordinary lawsuit and arbitration proceedings is too high. Therefore, in order to better protect the legitimate rights and interests of consumers, we need to set up an efficient online dispute resolution mechanism that can learn from the practice of the U.S. Financial and Consumer Bureau.

\section{References}

[1] Dahlberg T, Mallat N, Ondrus J, et al. Past, present and future of mobile payments research: A literature review[J]. Electronic Commerce Research and Applications, 2008, 7(2): 165-181.

[2] Pavlou P A, Gefen D. Building effective online marketplaces with institution-based trust[J]. Information systems research, 2004, 15(1): 37-59.

[3] Herbst A F. E-finance: Promises kept, promises unfulfilled, and implications for policy and research[J]. Global Finance Journal, 2001, 12(2): 205-215.

[4] Caudill E M, Murphy P E. Consumer online privacy: Legal and ethical issues[J]. Journal of Public Policy \& Marketing, 2000, 19(1): 7-19.

[5] Wang $\mathrm{H}$, Lee $\mathrm{M} \mathrm{K} \mathrm{O}$, Wang C. Consumer privacy concerns about Internet marketing[J]. Communications of the ACM, 1998, 41(3): 63-70.

[6] Clemons E K, Madhani N. Regulation of digital businesses with natural monopolies or third-party payment business models: Antitrust lessons from the analysis of Google[J]. Journal of Management Information Systems, 2010, 27(3): 43-80.

[7] González A G. PayPal: the legal status of C2C payment systems[J]. Computer law \& security review, 2004, 20(4): 293-299.

[8] Kimery K M, McCord M. Third-party assurances: Mapping the road to trust in e-retailing[J]. JITTA: Journal of Information Technology Theory and Application, 2002, 4(2): 63.

[9] Claessens S, Glaessner T, Klingebiel D. Electronic finance: reshaping the financial landscape around the world[J]. Journal of Financial Services Research, 2002, 22(1-2): 29-61.

[10] Shahrokhi M. E-finance: status, innovations, resources and future challenges[J]. Managerial Finance, 2008, 34(6): 365-398. 